\title{
Editorial Review of Volume 21
}

The study of society, like living in it, is a collective enterprise. In addition to their contributions on specific topics, the articles published in this volume of $\mathrm{CSSH}$ engage in a broader dialogue which this year has probed two themes in particular: the role of culture in shaping scientific, economic, and political behavior; and the impact of capitalism on social forms. The themes are old ones that, more precisely stated, now have renewed vitality; they also, like the revived interest in political economy, bridge academic disciplines and simple distinctions between 'values' and 'economics.'

The first of these themes was provocatively posed in the first issue by Maier's study of nineteenth-century Asante medical practices and Mitchell's study of physicians' views of French peasants in the eighteenth century. In the third number de Haas extended the discussion to a general method for connecting technology to culture in his article on photography. Related questions of cultural constraints also arose on a seemingly very different subject, regionalism-in the debate about Hechter's interpretation in the first number and in Gourevitch's and Pletsch's comparative analyses in the third. A good measure of the conditions that make ethnic or regional ties the basis for mobilization should be the social organizations that immigrants form, and appropriately CSSH has printed important articles on that including Hamilton's (also in the third number) on the Chinese case. Similar issues are illumined by studying the place of minorities in different societies, another subject that obviously demands comparison and has received it in these pages. The essays by Stephen Thompson and Takashi Maeyama, in this issue, thus intersect a whole network of previous discussions, on Jews in Morocco and Tunisia and Arabs in Israel (Tessler, 20:3), caste notions among Indian immigrants (Moore, 19:1), and regional associations (Skeldon, 19:4, and Jongkind, 16:4), but especially Wong's comparison of the assimilation of Chinese in New York and Lima (20:3). Thompson challenges the emphasis on differences in the receiving cultures, American and Peruvian, by comparing the place of the Japanese in these same societies. The problem is thus differently posed, with formal associations once more a crucial test; and Maeyama's treatment of the extraordinary organizations of the Japanese in Brazil underscores this in a poignant picture of the myths that sustained a minority in wartime.

The ability to keep in focus both values and established institutions, on the one hand, and the role of political power and market exigencies on the other, likewise accounted for the unevenness of economic change in British 


\section{2}

EDITORIAL REVIEW OF VOLUME 21

India and Communist China (Leonard and Solinger, in the second number). Such unevenness and complexity are not merely the result of cultural differences, a point elegantly made in this issue by Mary Jo Maynes, whose analysis of differing rates of schooling finds local forms of taxation more telling than the educational drive of Protestantism or indifference of Catholicism. Paradoxically, one "modernizing" change may inhibit another. (Maynes' emphasis supplements Harrigan's and Connor's discussions of secondary education, 17:3.) Yet established culture has its autonomy, too, and even religious forms can spur change while preserving continuity, a point emphasized by Gananath Obeyesekere in his review essay, and one illustrated before in discussions of Islamic education (Eickelman, 20:4) and of Buddhism and social control (Gombrich, 17:2).

The connections of culture and economic structure were explicitly explored in studies of how elite families in Latin America preserved their status from generation to generation (Balmori and Oppenheimer, and Lewin, in the second number), of the early nineteenth-century traditions of the French working class (Sewell, Reddy, and Truant in the second number) and were the nexus of debate between Stearns and O'Boyle on life style and power as indicators of social class (the third number). Expanding capitalism's pressure for social change is also a theme in most of these essays, and current attention to the impact of capitalist markets has reopened interest in classic questions about the effect of production for market on the organization of agricultural labor and what is 'feudal.' Such questions, too easily made a matter of abstract definition, are in fact central to current politics. In this volume they have been treated in terms of the very possibility of reform in developing societies (Tuma and Samoff in the first number) and the nature of political revolution in agricultural societies (Somers and Goldfrank, and Traugott, in the third number). This contemporary concern is continued in this issue with Ronald Herring's assessment of the late Ali Bhutto's attack on 'feudalism,' while the relationship of landholding, labor systems, and markets is given remarkable historical dimension by Alan Richards. Placed in comparative and concrete settings this broadened dialogue can benefit from the best work on slavery, serfdom, and agronomy as the review essays of Sidney Mintz and Folke Dovring remind us.

The articles printed in Volume 21 should, as always, be weighed primarily for their lasting contribution to particular topics, but the fact that each says something to several different fields, stimulates further comparison, and opens discussion across disciplines and countries and times is, incidentally, an essential part of the institutional vitality, cultural contribution, and role in the marketplace of this quarterly journal. 